\title{
THE IMPORTANCE OF SUBSIDIES FOR SME DEVELOPMENT IN THE AGRICULTURAL SECTOR OF SERBIA ${ }^{1}$
}

\section{Olivera Jovanović , Jovan Zubović ${ }^{3}$}

\begin{abstract}
Subsidies for the development of agriculture of the Republic of Serbia are an important instrument of agricultural policy that enables improving the position of agricultural holdings in the modern agribusiness environment, but also the business performances of small and medium-sized enterprises that have fulfilled the conditions for their use. As the needs and interests of primary farmers are different in relation to the needs and interests of other entities in the agrarian sector, the emergence of conflicting interests within the sector is not uncommon in low- and middle-income countries. The fact that business entities have different interests and different models of organizational structure implies a focus on the realization of different and uneven business goals. Accordingly, the subjects of research in this paper are subsidies for agricultural development as one of the current forms of institutional support. The subsidies are considered by analyzing their importance for the agrarian sector, aimed at enhancing the business performance of profit-oriented family farms registered as micro, small and medium-sized companies. The aim of the research is to review the types, planned and realized amounts of subsidies that are important for the development of small and medium-sized enterprises in the agricultural sector in the period from 2015 to 2019.
\end{abstract}

Key words: subsidies, national incentives, agriculture, SMEs, Serbia.

JEL ${ }^{4}$ : Q18, L53

\section{Introduction}

The offer of agricultural products of different degrees of processing is formed by enterprises of various sizes. Micro, small and medium-sized companies

1 This paper is part of research projects under the codes: 179015 (Challenges and Prospects for Structural Changes in Serbia: Strategic Directions for Economic Development and Harmonization with EU Requirements) and 31005 (Contemporary Biotechnological Approach to Drought Management in Serbian Agriculture), funded by the Ministry of Education, Science and Technology Development of the Republic of Serbia.

2 Olivera Jovanovic, M.A., Research Associate, Institute of Economic Sciences, Zmaj Jovina Street no. 12, 11000 Belgrade, Serbia, Phone: +381 112623 055, E-mail: olivera.jovanovic@,ien.bg.ac.rs

3 Jovan Zubovic, Ph.D., Senior Research Associate, Institute of Economic Sciences, Zmaj Jovina Street no. 12, 11000 Belgrade, Serbia, Phone: +381 112623 055, E-mail: jovan.zubovic@ien.bg.ac.rs

4 Article info: Review Article, Received: $24^{\text {th }}$ September 2019., Accepted: $30^{\text {th }}$ September 2019. 
registered in the official Register of agricultural holdings of the Ministry of Agriculture, Forestry and Water Management have a different position on the market compared to large ones, since they face problems and limitations with insufficient funds available to overcome them. Aside from the difficulty of obtaining financing for investment due to the slow turnover of capital, the risk of failure cannot be offset by the diversification of the product range. Specifically, large enterprises can produce more products, sometimes even in different categories, to offset the decline in demand for one product by the demand for another. Small and medium-sized enterprises cannot have the same production strategy as large ones because they do not have sufficient production capacities and therefore have limited sales opportunities. Therefore, they opt for those products that are likely to have greater success with consumers.

In order to improve the conditions for business development and the competitiveness of micro, small and medium-sized enterprises, taking into account their contributions to the overall economic progress of the national economy, the Government of the Republic of Serbia has adopted the "Strategy for supporting the development of small and medium-sized enterprises, entrepreneurship and competitiveness from 2015 to 2020”. On the other hand, a series of documents that make up the legislative and strategic framework of agribusiness development is directed at defining measures and activities for more efficient utilization of agricultural potential while adapting to current market trends. The most important among them is the strategic document governing long-term rural and agricultural development (Strategy for Agriculture and Rural Development of the Republic of Serbia for the period 2014-2024, adopted by the Ministry of Agriculture, Forestry and Water Management). The legislative framework highlights the Law on Incentives for Agriculture and Rural Development from 2016, defining the elements of agrarian policy and types of subsidies, ways of their use, as well as conditions for exercising rights over this type of national support.

According to the significance of the SMEs for the overall national economy, and following the facts that Serbia is a country with large chances for a stronger development of the agriculture, the main aim of authors' research is to investigate the type of the relationship between SMEs in agriculture and institutional support. Institutional support to SMEs and agricultural sector can be very diversified, but just one or several of them are effective. Because the type of the relationship depends on the quality of the data, In this paper authors will present descriptive statistics about SMEs in agriculture, main indicators of the development and descriptive review of the national incentives. 
In accordance with the simultaneous importance of the agrarian sector for the economic progress of the country and small and medium-sized enterprises that are the drivers of its development, the authors grouped the analysis into three parts. The first part consists of an analysis of the situation in the sector of small and mediumsized enterprises registered for agricultural activities in the period 2014-2017. The second part of the paper includes an overview of planned and realized amounts of national incentives, while the third part discusses the implementation of institutional support in the future.

\section{Methodology}

In order to realize the basic goal of the research presented in this paper, the authors used desk research to review relevant scientific papers about agricultural policy in low and middle income countries in the SEE region (specifically in the Republic of Serbia). While the main focus of the desk research was to examine the literature of domestic and foreign authors related to agrarian policy, the main aim of the empirical research was to collect the microdata about planned and realized amounts of the national incentives, especially subsidies.

Also, empirical research was conducted in 2019. The empirical research is important part of the overall research activities because it also collects the microdata about companies in the agrarian SMEs sector. Through empirical research, the authors had the opportunity to conduct several in-depth interviews with representatives of relevant institutions which was very useful. Main data resources in this paper are Directorate for Agrarian Payments, Statistical Office of the Republic of Serbia and Ministry of Economy. All relevant and interesting research information are incorporated in the following lines.

\section{Small and medium enterprises: The situation in the agrarian sector}

Serbia is one of the middle - income country in the SEE region where SMEs are very significant in overall development (Zubović, Jovanović, 2019). According to the 2017 SME Report (MERS, 2017), out of a total of 357,234 enterprises, 6,340 (1.8\%) were registered in the agrarian sector. They employed 22,011 workers, or $2.5 \%$ of the total number of employees in the SME sector in all sectors, while the turnover amounted to RSD 266,432 million. The following table (Table 1.) shows the main indicators of the SME sector in the four-year period. 
Table 1. SMEs in agriculture in the period 2014-2017

\begin{tabular}{|c|c|c|c|c|}
\hline Year & Micro & Small & Medium & Total \\
\hline \multicolumn{5}{|c|}{ Number of business entities } \\
\hline 2017 & 3,233 & 363 & 88 & 3,684 \\
\hline 2016 & 3,080 & 368 & 94 & 3,542 \\
\hline 2015 & 2,905 & 367 & 95 & 3,367 \\
\hline 2014 & 2,925 & 360 & 97 & 3,382 \\
\hline \multicolumn{5}{|c|}{ Number of employees } \\
\hline 2017 & 4,687 & 7,874 & 7,812 & 22,011 \\
\hline 2016 & 4,728 & 8,126 & 8,451 & 21,305 \\
\hline 2015 & 4,647 & 8,153 & 8,590 & 21,390 \\
\hline 2014 & 4,513 & 8,174 & 9,298 & 21,985 \\
\hline \multicolumn{7}{|c|}{ Turnover in million RSD } \\
\hline 2017 & 74,622 & 110,014 & 70,599 & 255,235 \\
\hline 2016 & 89,051 & 126,315 & 79,129 & 294,495 \\
\hline 2015 & 79,843 & 110,070 & 74,327 & 264,240 \\
\hline 2014 & 79,255 & 108,139 & 85,151 & 272,545 \\
\hline
\end{tabular}

Source: MERS, 2015/2016/2017/2018.

The number of companies, the number of employees and the turnover are the indicators that are most commonly used when analyzing the importance and contribution of activity to overall economic development. The SMEs sector in agriculture, forestry and water management did not experience significant fluctuations in the value of these indicators. The number of economic entities increased by $8 \%$ in the observed period, while the turnover decreased by $6.7 \%$. The number of employed workers also increased slightly. Considering the SME sector in agriculture compared to other economic activities, it can be concluded that this category of economy is very important for achieving higher rates of economic growth, given their business performance (Pantić, 2015).

The number of established SMEs in the agricultural sector in 2017 was 681, while the number of the shutdown ones was 374 . The net effect is positive, i.e. the number of established compared to the extinguished enterprises is greater, with a stable rate of survival $-79.6 \%$ of enterprises survived in 2017 compared to the year of foundation. In the observed four-year period, it is noted that, on average, the number of extinguished companies equals half of the number of newly established companies, while the survival rate of these enterprises was relatively stable - about $80 \%$.

The movement of indicators is influenced by the stability of the macroeconomic environment, the business environment, as well as the support of relevant institutions through a variety of programs and national incentives. Given that institutional support for the SMEs sector has improved significantly over the last decade, which 
can be deduced from the adopted strategies, work programs and their implementation (Jovanović, 2016), it is concluded that stability in the indicators of SME sector development is partly explained by the strengthening of the subsidy program, lending and providing other forms of business support. However, by looking at the survival rates of businesses in other industries, ranging between $85 \%$ and $95 \%$, there is room for further improvement of institutional support with longer-term positive effects on business and financial performance.

\section{National incentives: Support programs for SMEs in agriculture}

According to Popović and Grujić (2015) the republic budget transfer funds for the most of the subsidies and support programs goes directly to the to the users, and including agricultural subsidies that amount was $51.2 \%$ in 2008. In the same paper, Popović and Grujić (2015) argue that agricultural subsidies had a faster growth compared to the total subsidies in last years.

According to Zubović and Boškov (2013), modern agricultural needs to adapt to changes on the global market in order to be more competitive. Institutional framework is very important for the competitiveness of this sector. The realization of the goals of the Strategy of Agriculture and Rural Development of the Republic of Serbia for the period from 2014 to 2024 is implemented through appropriate support programs, which are supported by different institutions. Some of these are the Ministry of Economy, the Serbian Development Agency, the Serbian Development Fund, the Agrarian Payments Directorate, the Ministry of Agriculture, Forestry and Water Management and other. In addition to programs implemented at the national level, there are also programs implemented by local institutions and authorities.

Because Serbia is one of the several countries with middle - income, she can implement a good practice form other countries in the Western Balkan region and increase the total amount for subsidies or improve its effectiveness throught better structure. Comparing with Bosnia, the composition of the subsidies are similar between these two conutries. Institutions in Bosnia are mainly oriented on direct payment to producers - more than $40 \%$ of the total agriculture budget are direct payments (Zurovec et al., 2015). The main instrument of Macedonian agrarian policy are also direct payments to producers (Trendov et al., 2017).

Credit support as a financial instrument for the development of the SME in the agriculture sector is mainly implemented through the Development Fund of the Republic of Serbia. Credit support priorities are the promotion of balanced regional development, including underdeveloped areas, the enhancement of competitiveness 
and liquidity of the domestic economy, the promotion of employment, and the promotion of export-oriented goods. The forms of credit support provided by the Development Fund are as follows:

- Investment loan is intended for those companies that need funds to finance the purchase of equipment, machinery, plant, or for the construction or purchase of manufacturing or business premises.

- Loans for permanent working capital - intended for financing current liabilities arising in the ordinary course of business of the final beneficiary of the loan, referring to the procurement of raw materials, supplies, inventories and other manufacturing costs, trade receivables or trade payables.

- Short-term loans are intended for companies to improve their competitiveness and liquidity.

- Credit for maintaining current liquidity

- Loans for business entities in underdeveloped and highly underdeveloped areas - underdeveloped areas are defined in accordance with the Law on Regional Development, with the right to use this line of credit granted only to companies from these regions that achieved a positive financial result in the year before submission of credit support requests or have positive trends in the financial balance.

- Refinancing Loans - Refinancing funds can only be approved for legal entities that are predominantly manufacturing and employ a minimum of 50 workers.

The Agrarian Payments Directorate, established by the Ministry of Agriculture, Forestry and Water Management, can be classified as one of the most important institutions providing support to farms owned by natural persons, as well as to those family farms registered as legal entities. In order for an agricultural holding to use the resources approved by the Directorate, it is necessary to have it registered in the official Register of agricultural holdings. The support provided by the Ministry includes the approval of grants or subsidies that can be classified into five categories (Tables 2-4.): direct payments, rural development measures, special incentives for agriculture and rural development, credit support and IPARD funds. 
Table 2. Subsidies of the Agrarian Payments Directorate - Direct Payments in 2015 - 2019 (in RSD)

\begin{tabular}{|c|c|c|}
\hline Year & Planned Amount of Funds & Realized Amount of Funds \\
\hline 2019 & $23,920,314,000$ & $13,898,689,875^{*}$ \\
\hline 2018 & $16,221,813,000$ & $16,219,716,108$ \\
\hline 2017 & $16,302,453,000$ & $16,252,922,208$ \\
\hline 2016 & $16,435,670,000$ & $16,359,941,370$ \\
\hline 2015 & $17,513,624,997$ & $17,512,460,922$ \\
\hline
\end{tabular}

Source: DAP, 2019.

Note: *Funds realized as of 31.07.2019.

Direct payments are one of the types of subsidies whose beneficiaries may equally be family farms (registered as individuals) or companies. In view of the procedure granting this type of incentive, practice has shown that beneficiaries that are more frequent are legal entities that can satisfy all administrative requirements. Within direct payments, small and medium-sized enterprises may be granted premiums (milk premiums are dominant), recourse (monetary amounts paid for certain agricultural inputs) or production incentives. In the total amount of direct payments, the largest share is made by incentives for production (77\% in 2018), and this trend is present throughout the observed period. A significant change for funds is observed in 2019 , when the amount foreseen for this type of agrarian support increased by $15 \%$ compared to 2015.

Table 3. Subsidies of the Agrarian Payments Directorate - rural development measures for the period 2015-2019 (in RSD)

\begin{tabular}{|c|c|c|}
\hline Year & Planned Amount of Funds & Realized Amount of Funds \\
\hline 2019 & $8,000,000,000$ & $2,563,854,697 *$ \\
\hline 2018 & $3,434,443,157$ & $3,232,251,871$ \\
\hline 2017 & $6,947,000,000$ & $6,398,722,220$ \\
\hline 2016 & $3,420,600,000$ & $2,775,595,000$ \\
\hline 2015 & $1,025,000,000$ & $956,700,431$ \\
\hline
\end{tabular}

Source: DAP, 2019.

Note: *Funds realized as of 31.07.2019.

Unlike direct payments, the planned funds for rural development measures under national incentives show significant fluctuations. The highest amount of planned funds was recorded in 2019 and the lowest at the beginning of the observed period. Viewed by years, it can be noticed that there is a high level of utilization, i.e. realization of funds for rural development measures. Among them, the subsidies for improving competitiveness have the largest share, which is of great importance for the SME 
in the agrarian sector. Incentives for improving competitiveness in 2019 accounted for about $70 \%$ of the total planned funds under rural development measures (Labor informer, Agrarian Payments Directorate), while the rest goes to: incentives for the conservation and improvement of environment and natural resources; incentives for income diversification and improvement of quality of life in rural areas; incentives for the preparation and implementation of local rural development strategies and incentives for improving the system of knowledge creation and transfer.

Table 4. Subsidies of the Agrarian Payments Directorate - special incentives in agriculture and rural development for the period 2016-2019

\begin{tabular}{|c|c|c|}
\hline Year & Planned Amount of Funds & Realized Amount of Funds \\
\hline 2019 & $250,000,000$ & $2,191,582 *$ \\
\hline 2018 & $217,130,534$ & $198,601,389$ \\
\hline 2017 & $254,850,000$ & $149,644,986$ \\
\hline 2016 & $209,700,000$ & $180,903,447$ \\
\hline
\end{tabular}

Source: DAP, 2019.

Note: *Funds realized as of 31.07.2019.

Specific incentives in agriculture and rural development include several specific programs: incentives for marketing information systems in agriculture; incentives for the establishment, development and operation of accounting data systems on farms; incentives for the implementation of breeding programs; incentives for production of planting material and certification as well as incentives for promotional activities in agriculture and rural development. During the observed period, there was a slight fluctuation in the amount of funds planned for these purposes, and an increase of $17 \%$ was recorded in 2019 compared to 2016 . There is a high level of realization of the amount of funds, with the highest approval of incentives for the implementation of breeding programs. According to the Agrarian Payments Directorate, in 2018, 444 applications were approved to use this particular type of incentive.

Table 5. Subsidies of the Agrarian Payments Directorate - IPARD

\begin{tabular}{|c|c|c|}
\hline Year & Planned Amount of Funds & Realized Amount of Funds \\
\hline 2019 & $6,073,500,000$ & $55,484,863$ \\
\hline 2018 & $2,434,260,000$ & 0 \\
\hline 2017 & $1,000,000,000$ & 0 \\
\hline
\end{tabular}

Source: DAP, 2019.

Note: *Funds realized as of 31.07.2019. 
IPARD is an instrument for pre-accession assistance in rural development that provides financial assistance intended to strengthen the competitiveness of the food production and processing sector in order to adapt domestic products to all required EU standards. IPARD is intended for farmers - legal and natural persons, operating in the following regions: Belgrade region, Vojvodina, Šumadija region and Western Serbia as well as Southern and Eastern Serbia region. Although IPARD funding was planned, no incentives were realized during 2017 and 2018. In 2019, the first realizations of accepted funding requests were recorded.

The interest for using the Subsidies of the Agrarian Payments Directorate is extremely high; in 2018, a total of 327,119 applications were approved of agricultural producers - legal and natural persons, which indicates the importance of this type of national support for the development of businesses in the agrarian sector. Since the empirical analysis confirms the existence of delays in the implementation of the approved funds, and outstanding liabilities arise on a year-by-year basis, double problems may arise. On the one hand, arrears adversely affect financial balance of the Agrarian Payments Directorate, while delays in disbursement of funds to end-users endanger their operations, thereby diminishing the positive effects of subsidies on financial and business performance of SMEs and commercial family households.

\section{Conclusion}

During the four-year period, there has been a significant improvement in the quality and volume of institutional support for the development of the SME sector in all activities. With appropriate agrarian policy instruments, the business performance of SMEs in the agribusiness is being improved year by year. In addition to increasing the amount of available funds allocated from the state budget for various types of support, the activities within the complicated administrative procedures that need to be implemented in order to apply for incentives are also reduced. The increase in the number of approved requests for the use of funds is also noticed with the Development Fund (as the holder of credit support) and with the Agrarian Payments Directorate (which is the holder of subsidy support). Opportunities for business and start-up in the agricultural sector are significant given its capacity, but funding for risky agricultural production is often scarce. The support of public sector institutions is equally important in all aspects of business, both in providing additional funding, as well as in support of employment and in foreign trade activities. Strengthening support would increase the value of all business indicators of enterprises in the agrarian sector, and positive effects would be seen through the growth of the survival rate of enterprises compared to the year of establishment. In other words, adequate institutional support will extend the life expectancy of small or medium-sized enterprises in agriculture. 


\section{References}

1. DAP (2019). National subsidies related to agriculture and rural development. Data obtained upon request, Directorate for Agrarian Payments, September 2019, Belgrade, Serbia.

2. Jovanović, O. (2016). Institucionalna podrška razvoju preduzetništva poljoprivrede tokom strukturnih promena u Srbiji. In: Pravci strukturnih promena u procesu pristupanja Evropskoj uniji. Institute of Economic Sciences, Belgrade, Serbia, pp. 393-404.

3. MAFWM (2014). Strategy for Agriculture and Rural Development of the Republic of Serbia for the period 2014-2024. Ministry of Agriculture, Forestry and Water Management of the Republic of Serbia (MAFWM), Belgrade, Serbia.

4. MERS (2015). Report on SMEs and Entrepreneurship for 2014. Ministry of Economy of the Republic of Serbia (MERS), Sector for Development of Small and Medium Sized Enterprises and Entrepreneurship, Belgrade, Serbia.

5. MERS (2015a). Strategy for supporting the development of small and mediumsized enterprises, entrepreneurship and competitiveness from 2015 to 2020. Ministry of Economy of the Republic of Serbia (MERS), Belgrade, Serbia.

6. MERS (2016). Report on SMEs and Entrepreneurship for 2015. Ministry of Economy of the Republic of Serbia (MERS), Sector for Development of Small and Medium Sized Enterprises and Entrepreneurship, Belgrade, Serbia.

7. MERS (2017). Report on SMEs and Entrepreneurship for 2016. Ministry of Economy of the Republic of Serbia (MERS), Sector for Development of Small and Medium Sized Enterprises and Entrepreneurship, Belgrade, Serbia.

8. MERS (2018). Report on SMEs and Entrepreneurship for 2017. Ministry of Economy of the Republic of Serbia (MERS), Sector for Development of Small and Medium Sized Enterprises and Entrepreneurship, Belgrade, Serbia.

9. Pantić, O. (2015). Uloga sektora MSPP u strukturnim promenama poljoprivrede Republike Srbije. U: Strukturne promene u Srbiji - dosadašnji rezultati i perspektive, Institute of Economic Sciences, Belgrade, Serbia, pp. 331-345.

10.Popović, V., Grujić, B. (2015). Agricultural subsidies in the budget of the Republic of Serbia. Economics of Agriculture, 2(62):513-525.

11.Trendov, N., Olagunju, K., Presevski, M. (2017). Are agricultural subsidies efficient tool for agricultural sector of the Republic of Macedonia?. Bulgarian Journal of Agricultural Science, 3(23):363-369. 
12.Zubović, J., Boškov, V. (2013). Elasticity of Agricultural Labour Market: the case of Zrenjanin District. In: Sustainable Agriculture and Rural Development in Terms of the Republic of Serbia Strategic Goals Realization within the Danube Region, Institute of Agricultural Economics, Belgrade, Serbia, pp. 366-381.

13.Zubović, J., Jovanović, O. (2019). Small and Medium Enterprises in selected SEE countries - a drivers of rural development. In: Sustainable Agriculture and Rural Development in Terms of the Republic of Serbia Strategic Goals Realization within the Danube Region: sustainability and multifuncionality. Institute of Agricultural Economics, Belgrade, Serbia, pp. 353-369.

14.Zurovec, O., Vedeld, O. P., Sitaula, B. K. (2015). Agriculture Sector of Bosnia and Herzegovina and climate change: Challenges and Oportunities. Agriculture, 2(5):245-266. 